\title{
WHERE DO CANADIAN BURROWING OWLS SPEND THE WINTER?
}

PAUL C. JAMES, Museum of Natural History, Wascana Park, Regina, Saskatchewan. S4P 3V7

The Burrowing Owl is currently classified by the Committee on the Status of Endangered Wildlife in Canada (COSEWIC) as threatened. This means that it is likely to become endangered if the factors affecting its vulnerability are not reversed. Many such potential factors have been identified including habitat loss, pesticides, and other types of mortality, and studies are now underway in Canada in order to evaluate these limiting factors. ${ }^{1,3}$ While Canadian Burrowing Owls are migratory, very little is known about their migration routes and wintering areas. ${ }^{2}$ This is obviously a critical weakness because the limiting factor(s) affecting their population may be operating at those times of the year. It is generally assumed that these Canadian Burrowing Owls spend the winter in the southern United States; however, I present evidence here to show that the Canadian population is probably spending the winter south of the United States. ${ }^{4}$

Methods I obtained all North American banding and bandrecovery data (up to and including 1987) for Burrowing Owls from the Bird Banding Office in Ottawa and extracted the following information:

1. The total number of owls banded in Canada.

2. The total number of owls banded in the United States.

3. The number of Canadian-banded owls recovered in the United States from November to February inclusive.

4. The number of American-banded owls recovered in the United States from November to February inclusive.

Assuming that Canadian owls spend the winter months in the United States, their recovery rate there during the four winter months should be more or less the same as for the American-banded owls. If it is not, then Canadian owls must be travelling further south into Central America for the winter.

Results Of 2,512 American-banded Burrowing Owls $25(1 \%)$ have been recovered in the United States from November through February. In sharp contrast, not one of 1,701 Canadian-banded owls has been recovered there during this period. This difference in recovery rates between the Canadian and American birds is significantly different $\left(X^{2}=\right.$ 17.05, $P<0.005)$. Three Canadianbanded owls have, however, been recovered at other times of the year in the United States (Figure 1). One was recovered in Nebraska in September; the Texas owl was recovered in October; and the Colorado owl in April. 
Discussion The significant difference between the recovery rates of Canadian-banded and Americanbanded Burrowing Owls in the United States during November to February supports the suggestion that Canadian owls are wintering in Central America. If so, then a greater urgency exists with respect to the discovery of their wintering grounds as Central America is facing tremendous conservation problems. Based on this, I suggest that the three Canadian owls recovered in the United States were migrating birds, two going south and one coming north.

Further support for the suggestion that Canadian Burrowing Owls are wintering in Central America comes from the fact that three Americanbanded owls have been recovered during November to February in Mexico. These owls originated in California, Utah, and Oklahoma, respectively. If the principles of "leapfrog" migration hold for Burrowing Owls, then we might also expect the more northerly-breeding Canadian

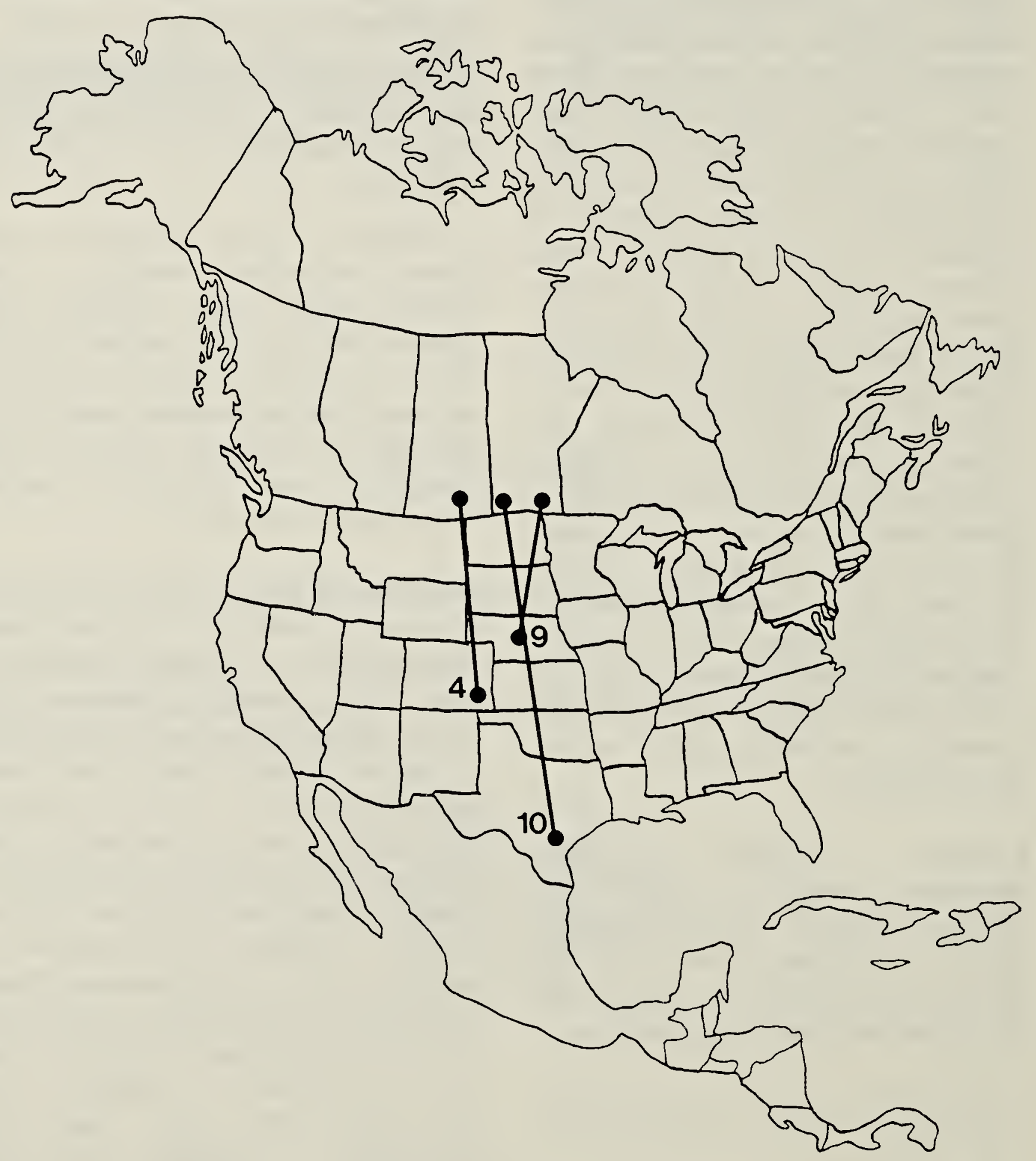

Figure 1. Recoveries of Canadian Burrowing Ow/s from the United States. The numbers denote the month in which the recovery was made. 
birds to winter further south than the American owls. ${ }^{5}$ That we have yet to receive a banding recovery of a $\mathrm{Ca}$ nadian owl from Central America is likely due to the lower probability of receiving a return from this region.

Clearly, greater emphasis needs to be placed on banding Burrowing Owls in Canada in order to increase the chances of recoveries being niade further to the south. In addition, it might be useful if a Burrowing Owl banding program was started in Mexico during the winter. In any event, it would appear that greater cooperation is required between Canada and the countries of Central America with respect to Burrowing Owl conservation.

\section{Acknowledgements}

I thank Ann Demers of the Bird Banding Office in Ottawa for providing access to their Burrowing Owl banding information. My studies on
Burrowing Owls have been supported by the Canadian Wildlife Service, World Wildlife Fund, and FMC Corporation of Canada.

1. HAUG, E.A. 1985. Observations of the breeding ecology of Burrowing Owls in Saskatchewan. Unpublished M.Sc. thesis, University of Saskatchewan, Saskatoon.

2. JAMES, P.C., and T.J. ETHIER. 1989. Trends in the winter distribution and abundance of Burrowing Owls in North America. Am. Birds 43:12241225.

3. JAMES, P.C. and G.A. FOX. 1987. Effects of some insecticides on productivity of Burrowing Owls. Blue Jay 45:65-71.

4. WEDGWOOD, J.A. 1978. The status of the Burrowing Owl in Canada. Committee on the Status of Endangered Species in Canada, Toronto.

5. WELTY, J.C. and L. BAPTISTA. 1988. The life of birds. Saunders College Publishing, New York. 581 pp.

To the labourer in the sweat of his labour, the raw stuff on his anvil is an adversary to be conquered. So was wilderness an adversary to the pioneer. But to the labourer in repose, able for the moment to cast a philosophical eye on the world, the same raw stuff is something to be loved and cherished, because it gives definition and meaning to his life. This is a plea for the preservation of some tag-ends of wilderness, as museum pieces, for the edification of those who may one day wish to see, feel, or study the origins of their cultural inheritance. Aldo Leopold, 1949. A Sand County Almanac. Oxford. 